\title{
Article
}

\section{Botulinum Neurotoxin Injections in Childhood Opisthotonus}

\author{
Mariam Hull ${ }^{1,2, * \mathbb{D}}$, Mered Parnes ${ }^{1,2} \mathbb{D}$ and Joseph Jankovic ${ }^{2}$ \\ 1 Section of Pediatric Neurology and Developmental Neuroscience, Texas Children's Hospital and Baylor \\ College of Medicine, Houston, TX 77030, USA; parnes@bcm.edu \\ 2 Parkinson's Disease Center and Movement Disorders Clinic, Department of Neurology, \\ Baylor College of Medicine, Houston, TX 77030, USA; josephj@bcm.edu \\ * Correspondence: mariam.hull@bcm.edu
}

Citation: Hull, M.; Parnes, M.; Jankovic, J. Botulinum Neurotoxin Injections in Childhood Opisthotonus. Toxins 2021, 13, 137. https://doi.org/ $10.3390 /$ toxins 13020137

Received: 25 January 2021

Accepted: 10 February 2021

Published: 12 February 2021

Publisher's Note: MDPI stays neutral with regard to jurisdictional claims in published maps and institutional affiliations.

\begin{abstract}
Opisthotonus refers to abnormal axial extension and arching of the trunk produced by excessive contractions of the paraspinal muscles. In childhood, the abnormal posture is most often related to dystonia in the setting of hypoxic injury or a number of other acquired and genetic etiologies. The condition is often painful, interferes with ambulation and quality of life, and is challenging to treat. Therapeutic options include oral benzodiazepines, oral and intrathecal baclofen, botulinum neurotoxin injections, and deep brain stimulation. Management of opisthotonus within the pediatric population has not been systematically reviewed. Here, we describe a series of seven children who presented to our institution with opisthotonus in whom symptom relief was achieved following administration of botulinum neurotoxin injections.
\end{abstract}

Keywords: opisthotonus; opisthotonos; axial dystonia; botulinum toxin

Key Contribution: This is the first series of pediatric patients with opisthotonus treated with botulinum neurotoxin injections. Botulinum neurotoxin injections should be added to the armamentarium of treatment options in children with axial dystonia, including opisthotonos.

\section{Introduction}

Opisthotonus, derived from the Greek "opistho" meaning behind and "tonos" meaning tone, was described by Nayler in 1803 within the context of tetanus as "such rigid contractions of those of the back, as to draw his head forcibly backwards at the same that his chest was considerably elevated" and described his expression as "bearing the strongest possible marks of the agony he suffered" [1]. Later, it was described by Charcot in 1887 as "arc de cercle", or arching of the body such that the patient is suspended above the bed by the head and the heels [2]. Charcot's description of abnormal posture was in the context of hysteroepileptic spells, later classified as psychogenic or functional dystonia [3,4]. Opisthotonus involves forceful axial extension of the trunk and also neck (retrocollis), caused by involuntary contractions of the paraspinal muscles, often associated with dystonic posturing of arms and legs (Figure 1) [5]. Although most frequently attributed to dystonia, there are many causes of opisthotonus that have been identified (Table 1). While in adults, the most common cause of opisthotonus is tardive dystonia [6], typically associated with adduction of the shoulders and extension/pronation of the arms, the most common causes of childhood opisthotonus are perinatal hypoxic-ischemic injury, and genetic/metabolic disorders which often present as a cerebral palsy phenotype [5].

Opisthotonus represents one of several abnormal axial skeletal abnormalities encountered in adult and pediatric populations, also including camptocormia, scoliosis, and other postural abnormalities $[7,8]$. It can be persistent and severe, occurring in-termittently or for sustained periods throughout the day, and when it presents as such, it is incompatible with living comfortably at home. If left untreated, many patients with these axial abnormalities develop contractures, fixed deformities due to shorten-ing of muscles and tendons. 
In some cases of dystonic opisthotonus, the intense con-tractions of the paraspinal muscles can lead to dystonic storm (also known as status dystonicus) $[9,10]$. This potentially fatal condition is characterized by persistent, worsening dystonia associated with interference with sleep as well at least one meta-bolic disturbance: (1) fever not due to infectious etiology, (2) abnormal electrolytes, (3) elevated CK $\geq 1000$, (4) myoglobinuria [10]. Although relatively rare, dystonic storm is a life-threatening emergency and its complications can lead to respiratory failure, re-nal failure, or even death $[10,11]$.

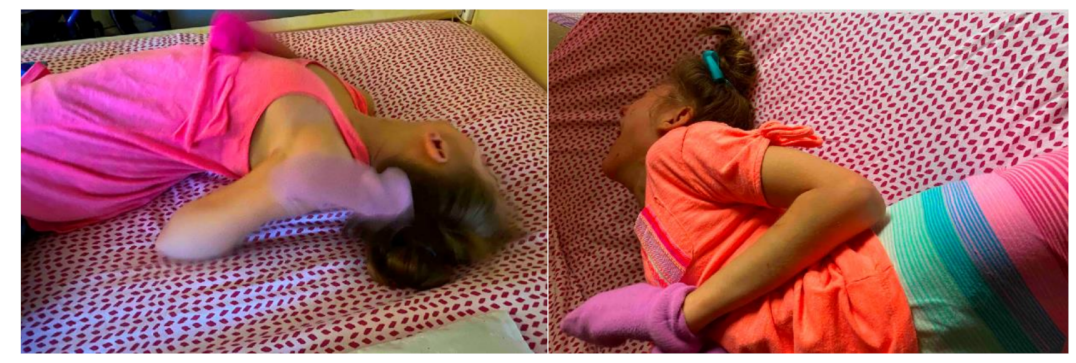

Figure 1. Illustrative photographs of opisthotonus of patient 4 prior to receiving treatment displaying characteristic axial extension of the trunk and neck.

Table 1. Etiologies of opisthotonus.

\begin{tabular}{|c|c|}
\hline Acquired & Genetic/Metabolic \\
\hline Hypoxic injury & Krabbe disease [12] \\
\hline Perinatal asphyxia [5] & Gaucher disease [13] \\
\hline Near-drowning [5] & Adenylosuccinate lyase deficiency [14] \\
\hline Cardiac/respiratory arrest [2] & Lesch-Nyhan syndrome [15] \\
\hline Traumatic asphyxia [2] & Glutaric aciduria [16] \\
\hline Infectious/Post-infectious & Maple syrup urine disease [17] \\
\hline Meningitis $[18,19]$ & Monoamine neurotransmitter defect $[20,21]$ \\
\hline Encephalitis $[22,23]$ & Wilson disease [24] \\
\hline Tetanus $[1,25-28]$ & $\begin{array}{l}\text { Neurodegeneration with brain iron accumulation (NBIA), e.g., } \\
\text { pantothenate kinase-associated neurodegeneration (PKAN) [15] }\end{array}$ \\
\hline Rabies [29] & Other genetic disorders ${ }^{1}[21,30]$ \\
\hline Neurosyphilis [31] & \\
\hline Cerebral malaria [12] & \\
\hline Toxins/elevated toxic metabolites & \\
\hline Kernicterus [12] & \\
\hline Strychnine [32] & \\
\hline Phencyclidine [32] & \\
\hline Phenothiazines [32] & \\
\hline Propofol $[33,34]$ & \\
\hline Methoxphenidine [35] & \\
\hline Neonatal caffeine overdose [32] & \\
\hline Increased Intracranial Pressure & \\
\hline Subarachnoid hemorrhage [5] & \\
\hline Intracerebral hemorrhage [5] & \\
\hline Hydrocephalus [36] & \\
\hline Mass/Tumor [36] & \\
\hline Autoimmune & \\
\hline Stiff-person syndrome [37] & \\
\hline Anti-NMDA receptor encephalitis [22] & \\
\hline Other & \\
\hline Functional (psychogenic) dystonia $[3,4,38]$ & \\
\hline Tardive dystonia $[6,30,39-43]$ & \\
\hline Malignant catatonia [29] & \\
\hline Brainstem/cerebellar malformation [44] & \\
\hline Epilepsy [12] & \\
\hline
\end{tabular}

${ }^{1}$ Any genetic syndromes with prominent dystonia have the potential to manifest opisthotonus. 
Treatment of opisthotonus is multifactorial, first targeting reversible causes such as discontinuation of the offending dopamine-receptor blocking drugs that may be causing acute or tardive dystonia, and the consideration of disease-specific therapies. In most cases, no such interventions are available, and supportive measures are employed, often consisting of a tiered approach beginning with oral medications (benzodiazepines, baclofen, and anticholinergics), and in more refractory cases requiring intravenous benzodiazepines for exacerbations and/or surgical interventions such as intrathecal baclofen pump or deep brain stimulation [45-47].

Over the past half-century, botulinum neurotoxin (BoNT) has emerged as one of the most versatile therapeutics in neurologic and non-neurologic disorders [48]. There are dozens of indications in the field of movement disorders alone [49], including treatment of spasticity and a variety of abnormal involuntary movements such as tremor, tics, hemifacial spasm, and most commonly focal/segmental dystonia [50]. In children with refractory generalized dystonia, areas of the body that are dispropor-tionately affected, or in which the dystonia causes a great deal of discomfort, can also be selectively targeted with BoNT. It acts primarily by inhibiting the release of acetyl-choline from the presynaptic nerve terminal through interfering with fusion of the synaptic vesicle with the plasma membrane at the level of the neuromuscular junction.

Here, we describe a series of children suffering from opisthotonus whose symptoms were adequately controlled using BoNT injections.

\section{Results}

We evaluated seven patients (four female), age range 15 months to 13 years, all with opisthotonus, who were treated at our institution with BoNT (Table 2). Etiologies varied, with three due to identified genetic causes including pantothenate kinase asso-ciated neurodegeneration (PKAN), hypomyelinating leukodystrophy-14, CASK-related disorder, and a single case with undetermined, likely genetic etiology with normal im-aging and lack of other risk factors. Three of the patients presented with dystonic storm.

Table 2. Characteristics of patients undergoing treatment of opisthotonus.

\begin{tabular}{cccccc}
\hline Patient & Sex & Age & Genetic vs. Acquired Etiology of Opisthotonus & Weight (kg) & History of Dystonic Storm \\
\hline 1 & M & $15 \mathrm{mo}$ & Acquired-Post-infectious & 7.3 & Yes \\
2 & F & $26 \mathrm{mo}$ & Genetic-Hypomyelinating leukodystrophy-14 & 8.5 & Yes \\
3 & M & $8 \mathrm{yr}$ & Genetic-NBIA/PKAN & 23.7 & No \\
4 & $\mathrm{~F}$ & $10 \mathrm{yr}$ & Acquired-Perinatal HIE & 25.7 & Yes \\
5 & $\mathrm{~F}$ & $3 \mathrm{yr}$ & Genetic-presumed & 14.7 & No \\
6 & M & $26 \mathrm{mo}$ & Genetic-CASK-related disorder & 34.4 & No \\
7 & F & $13 \mathrm{yr}$ & Acquired-Tardive dystonia & No \\
\hline
\end{tabular}

$\mathrm{M}=$ male, $\mathrm{F}=$ female, NBIA = neurodegeneration with brain iron accumulation, $\mathrm{PKAN}$ = pantothenate kinase associated neurodegeneration, $\mathrm{HIE}=$ hypoxic-ischemic insult, $\mathrm{CASK}=$ calcium/calmodulin-dependent serine protein kinase gene .

All patients were also treated with oral clonazepam and baclofen with partial though insufficient benefit. Two patients received trials of oral clonidine which was limited by excessive somnolence and hypotension as well as no clear improvement in opisthotonus, and therefore discontinued in both patients. One patient had presumed tardive dystonia and akathisia and was also treated with tetrabenazine, which was helpful for the akathisia, but with no clear improvement in the axial dystonia. The three patients who presented with dystonic storm were also managed with intrave-nous sedation, which led to control of symptoms until attempting to wean the intra-venous therapies, at which time posturing worsened.

Sites and dosing were chosen based on the involved muscles and estimated muscle mass and force of muscle contraction. All patients received onabotulinumtoxinA injections in the paraspinal muscles and six patients received injections at other sites in-volved, with the most common being splenius capitis for management of concurrent retrocollis 
(five out of seven patients) (Table 3). Dosing to the paraspinal muscles ranged between 120 to 300 units (average 215.7 units) and were divided into three to five injections on each side. Total units administered ranged between 150 to 650 units (average 341.4 units). Although the dosing regimen was not planned using weight-based calculations, total units administered per kilogram for these patients ranged from 16.7 to $23.8 \mathrm{U} / \mathrm{kg}$ (average $19.6 \mathrm{U} / \mathrm{kg})$.

All patients showed an improvement in opisthotonus within 3-14 days (average 6.1 days). Arching improved notably on examination of each child, and improvement was deemed to be of a meaningful and sufficient degree by caregivers of all injected children. There were no adverse effects with the exception of one patient who experi-enced neck extensor weakness, which resolved over a period of weeks and did not re-cur with subsequent injections omitting the splenius capitis. Four of seven patients re-quired repeat injections approximately three months following initial injections. No patient in this series has required escalation of treatment to involve surgical manage-ment of tone thus far. See Video S1 and Video S2 for illustrative cases before and after treatment. 
Table 3. Botulinum neurotoxin dosing regimens for patients with prominent opisthotonus.

\begin{tabular}{|c|c|c|c|c|c|c|c|c|c|}
\hline Patient & $\begin{array}{l}\text { Paraspinal } \\
\text { Dosing } \\
\text { (Units) }\end{array}$ & $\begin{array}{l}\text { Other Muscles } \\
\text { Injected }\end{array}$ & $\begin{array}{l}\text { Total Dose } \\
\text { (Units) }\end{array}$ & $\begin{array}{l}\text { Latency } \\
\text { (Days) }\end{array}$ & $\begin{array}{l}\text { Adverse } \\
\text { Effects }\end{array}$ & $\begin{array}{l}\text { Duration } \\
\text { of Benefit } \\
\text { (Weeks) }\end{array}$ & Outcome & $\begin{array}{l}\text { Repeat } \\
\text { Injections } \\
\text { Required }\end{array}$ & Other Treatments ${ }^{1}$ \\
\hline 1 & 150 & None & 150 & 3 & None & 12 & $\begin{array}{l}\text { Complete resolution of } \\
\text { opisthotonus during } \\
\text { maximal effect }\end{array}$ & Yes & $\begin{array}{l}\text { Baclofen, clonazepam, diazepam, } \\
\text { lorazepam, clonidine }\end{array}$ \\
\hline 2 & 120 & Splenius capitis & 170 & 5 & None & 14 & $\begin{array}{l}\text { Complete resolution of } \\
\text { opisthotonus during } \\
\text { maximal effect }\end{array}$ & Yes & $\begin{array}{l}\text { Clonazepam, midazolam, } \\
\text { dexmedetomidine, baclofen }\end{array}$ \\
\hline 3 & 260 & $\begin{array}{l}\text { Triceps brachii, } \\
\text { pectoralis major, } \\
\text { gluteus } \\
\text { maximus }\end{array}$ & 400 & 14 & None & $14-16$ & $\begin{array}{l}\text { Complete resolution of } \\
\text { opisthotonus during } \\
\text { maximal effect }\end{array}$ & Yes & Clonazepam, baclofen, tetrabenazine \\
\hline 4 & 300 & $\begin{array}{l}\text { Splenius capitis, } \\
\text { sternocleido- } \\
\text { mastoid }\end{array}$ & 430 & 6 & None & $12-16$ & $\begin{array}{l}\text { Complete resolution of } \\
\text { opisthotonus during } \\
\text { maximal effect }\end{array}$ & $\mathrm{No}^{2}$ & $\begin{array}{c}\text { Clonazepam, lorazepam, diazepam, } \\
\text { baclofen, carbidopa/levodopa, } \\
\text { gabapentin, dexmedetomidine, } \\
\text { morphine }\end{array}$ \\
\hline 6 & 220 & Splenius capitis & 290 & 3 & None & $12-14$ & $\begin{array}{l}\text { Complete resolution of } \\
\text { opisthotonus during } \\
\text { maximal effect with } \\
\text { gradual wearing off, } \\
\text { remaining dystonia not } \\
\text { impairing }\end{array}$ & No & Clonazepam, baclofen \\
\hline 7 & 300 & $\begin{array}{l}\text { Splenius capitis, } \\
\text { gastrocnemeus }\end{array}$ & 650 & 5 & $\begin{array}{c}\text { Neck } \\
\text { weakness }^{2}\end{array}$ & 16 & $\begin{array}{l}\text { Complete resolution of } \\
\text { opisthotonus during } \\
\text { maximal effect }\end{array}$ & Yes & $\begin{array}{l}\text { Clonazepam, lorazepam, diazepam, } \\
\text { trihexyphenidyl, baclofen, haloperidol, } \\
\text { tetrabenazine, guanfacine, clonidine, } \\
\text { carbidopa/levodopa, propranolol, } \\
\text { carbamazepine, topiramate, } \\
\text { duloxetine, cyclobenzaprine, } \\
\text { methocarbamol, morphine, ketamine }\end{array}$ \\
\hline
\end{tabular}

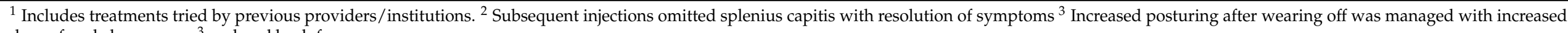
dose of oral clonazepam ${ }^{3}$ and oral baclofen. 


\section{Discussion}

This is the first report of childhood opisthotonus successfully treated with BoNT injections. The first description of adequate treatment of opisthotonus was by Nayler in 1803 in which he treated a 36-year-old man suffering from presumed tetanus fol-lowing a farming injury. Nayler quickly began treatment of the man which included "bladders of warm water to his feet, forty drops of laudanum to be taken every four hours in a camphorated mixture with tincture of castor." When there was no im-provement, he also ordered "wine freely, to the amount of a bottle in the day with a strong decoction of the bark and valerian, at the same time a liniment well charged with opium was rubbed into his chest and limbs twice a day" [1]. After some period of time had passed, the patient's symptoms eventually improved.

In 1877, another patient was reported with opisthotonus, as a result of an empy-ema following a traumatic brain injury. He was treated with "a mixture containing eighty grains of chloral-hydrate, half a drachm of extractum opii liquidum, and cam-phor" [51].

Since then, the approach to treatment of opisthotonus has been largely empirical and unsuccessful, typically involving a trial of several oral medications [30]. It was not until 1991, when Narayan and colleagues treated a patient with severe opisthotonus and generalized dystonia suffering from dystonic storm with urgent intrathecal baclo-fen that the use of more invasive measures became more common [47].

Further reports of surgical management of opisthotonus include deep brain stimulation [46] and intrathecal baclofen [5,13,47], each with clinical benefit. However, not all patients are good surgical candidates, the procedures are not without risks, both intraoperatively and long-term, and there can be insufficient benefit from either surgical treatment.

Our series of patients provides evidence that there is a role for BoNT injections in combination with pharmacotherapy, and prior to or supplemental to surgical interventions, in children with axial dystonia, including opisthotonus. Retrospective studies have reported doses of up to $15-20 \mathrm{U} / \mathrm{kg}$, and total doses of 800-1200 U have been safe; however, there have not been any large prospective studies in children determining a true upper dose limit [52-55]. Furthermore, the treatment was well-tolerated within this group, with no serious adverse events, and only a single case of transient neck ex-tensor weakness. None of the seven patients treated with injections required surgical treatment.

The three patients who did not require repeat injections in the months immedi-ately following initial injections may not have needed them due to the fluctuating na-ture of their underlying dystonia. This was evidenced by the eventual decrease in pos-turing even in sites not injected. Other potential reasons for improvement of dystonia also include management of pain, constipation, underlying infection, or other potential triggers of worsening dystonia, as well as maturing neural networks within the young-er population. Repeat injections remain an option, should dystonia become exacerbat-ed again in the future.

Limitations of this study include its retrospective, open-label design. Injections were performed using anatomic landmarks, without electromyogram or ultrasound guidance. Moreover, there is no objective scoring system that is clearly applicable to the pediatric population, though by subjective report, video (Video S1, Video S2), and clinical documentation, there was clear improvement of opisthotonus in these patients.

\section{Conclusions}

Despite the retrospective, small, and open-label design, our study provides evidence that BoNT injections into paraspinal muscles ameliorates childhood opisthotonus without serious adverse effects. This treatment should be added to the armamentaria of treatment options for this form of axial dystonia, particularly in cases refractory to oral medications. Of note, over half of the patients reviewed here are believed to have a genetic etiology for their opisthotonus. 


\section{Materials and Methods}

Here, we describe seven patients who presented to our center for management of opisthotonus and were treated with BoNT injections. Patients were followed clinically and we discussed features, dosing regimen, and outcomes through a review of clinical documentation and laboratory and radiology reports.

Supplementary Materials: The following are available online at https:/ /www.mdpi.com/2072-6 651/13/2/137/s1. Video S1: Patient 1 prior to botulinum neurotoxin injections and nine days following injections. Video S2: Patient 2 prior to botulinum neurotoxin injections and five days following injections.

Author Contributions: Conceptualization and methodology, M.H. and M.P.; writing-original draft preparation, M.H.; writing—review and editing, supervision, M.P. and J.J. All authors have read and agreed to the published version of the manuscript.

Funding: This research received no external funding.

Institutional Review Board Statement: The study was conducted according to the guidelines of the Declaration of Helsinki, no IRB was required for preparation of this case series, ethical guidelines were followed to assure patient privacy was maintained. Written consent from patient guardians was obtained prior to obtaining video and images for purposes of education within a medical peer reviewed journal.

Informed Consent Statement: Informed consent was obtained from all patient guardians and obtained prior to acquiring video and images.

Data Availability Statement: The data presented in this study are available on request from the corresponding author. The data are not publicly available to maintain patient privacy.

Conflicts of Interest: The authors declare no conflict of interest.

\section{References}

1. Nayler, R. Case of Opisthotonos, Successfully Treated. Med. Phys. J. 1803, 10, 492-494. [PubMed]

2. Diesing, T.S.; Wijdicks, E.F. Arc de cercle and dysautonomia from anoxic injury. Mov. Disord. 2006, 21, 868-869. [CrossRef]

3. Goetz, C. Charcot, hysteria, and simulated disorders. Handb. Clin. Neurol. 2016, 139, 11-23. [CrossRef] [PubMed]

4. Thenganatt, M.A.; Jankovic, J. Psychogenic (Functional) Movement Disorders. Contin. Lifelong Learn. Neurol. 2019, 25, 1121-1140. [CrossRef]

5. Ceulemans, B.; Van Rhijn, J.; Kenis, S.; Krols, R.; Laridon, A.; Van Havenbergh, T. Opisthotonus and intrathecal treatment with baclofen (ITB) in children. Eur. J. Nucl. Med. Mol. Imaging 2007, 167, 641-645. [CrossRef]

6. Savitt, D.; Jankovic, J. Tardive syndromes. J. Neurol. Sci. 2018, 389, 35-42. [CrossRef] [PubMed]

7. Wijemanne, S.; Jankovic, J. Hand, foot, and spine deformities in parkinsonian disorders. J. Neural Transm. 2019, 126, 253-264. [CrossRef]

8. Ali, F.; Matsumoto, J.Y.; Hassan, A. Camptocormia: Etiology, Diagnosis, and Treatment Response. Neurol. Clin. Pract. 2018, 8, 240-248. [CrossRef]

9. Opal, P.; Tintner, R.; Jankovic, J.; Leung, J.; Breakefield, X.O.; Friedman, J.; Ozelius, L. Intrafamilial phenotypic variability of the DYT1 dystonia: From asymptomaticTOR1A gene carrier status to dystonic storm. Mov. Disord. 2002, 17, 339-345. [CrossRef]

10. Allen, N.M.; Lin, J.-P.; Lynch, T.; King, M.D. Status dystonicus: A practice guide. Dev. Med. Child Neurol. 2014, 56, 105-112. [CrossRef]

11. Thakkar, P.; Naveen, B.P.; Yoganathan, S.; John, J.A.; Thomas, M. Status dystonicus: Diagnosis and management of a rare and challenging entity. J. Pediatr. Rehabil. Med. 2019, 12, 71-74. [CrossRef]

12. Christensen, R.D.; Yaish, H.M.; Wiedmeier, S.E.; Reading, N.S.; Pysher, T.J.; Palmer, C.; Prchal, J.T. Neonatal Death Suspected To Be From Sepsis Was Found To Be Kernicterus With G6PD Deficiency. Pediatrics 2013, 132, 1694-1698. [CrossRef] [PubMed]

13. Hori, Y.S.; Fukuhara, T.; Aoi, M.; Ochi, M.; Furujo, M. Intrathecal Baclofen Pump Implantation for Type 2 Gaucher Disease. Pediatr. Neurosurg. 2017, 52, 331-335. [CrossRef] [PubMed]

14. Jurecka, A.; Opoka-Winiarska, V.; Rokicki, D.; Tylki-Szymańska, A. Neurologic Presentation, Diagnostics, and Therapeutic Insights in a Severe Case of Adenylosuccinate Lyase Deficiency. J. Child Neurol. 2011, 27, 645-649. [CrossRef]

15. Stamelou, M.; Lai, S.C.; Aggarwal, A.; Schneider, S.A.; Houlden, H.; Yeh, T.-H.; Batla, A.; Lu, C.-S.; Bhatt, M.; Bhatia, K.P. Dystonic opisthotonus: A "red flag" for neurodegeneration with brain iron accumulation syndromes? Mov. Disord. 2013, 28, 1325-1329. [CrossRef] [PubMed]

16. Whelan, D.T.; Hill, R.; Ryan, E.D.; Spate, M. L-Glutaric acidemia: Investigation of a patient and his family. Pediatrics 1979, 63, 88-93. [PubMed] 
17. Kültürsay, N.; Kütükçüler, N.; Büyükgebiz, B.; Kleijer, W.J. A case of maple syrup urine disease misdiagnosed as Tetanus neonatorum on admission. Pediatr. Int. 1994, 36, 284-286. [CrossRef]

18. Kimberlin, D.W. Meningitis in the neonate. Curr. Treat. Options Neurol. 2002, 4, 239-248. [CrossRef]

19. Ramdhani, N.A.; Sikma, M.A.; Witkamp, T.D.; Slooter, A.J.; De Lange, D.W. Paroxysmal autonomic instability with dystonia in a patient with tuberculous meningitis: A case report. J. Med. Case Rep. 2010, 4, 304. [CrossRef]

20. Lee, J.-H.; Ki, C.-S.; Kim, D.-S.; Cho, J.-W.; Park, K.-P.; Kim, S. Dopa-responsive Dystonia with a Novel Initiation Codon Mutation in the GCH1 Gene Misdiagnosed as Cerebral Palsy. J. Korean Med. Sci. 2011, 26, 1244-1246. [CrossRef]

21. Manegold, C.; Hoffmann, G.F.; Degen, I.; Ikonomidou, H.; Knust, A.; Laaß, M.W.; Pritsch, M.; Wilichowski, E.; Hörster, F. Aromatic l-amino acid decarboxylase deficiency: Clinical features, drug therapy and follow-up. J. Inherit. Metab. Dis. 2009, 32, 371-380. [CrossRef]

22. Delgado-García, G.; Cano-Nigenda, V.; Abundes-Corona, A.; Carrillo-Loza, K.; Calleja-Castillo, J.; Flores-Rivera, J. Opisthotonus (arc de cercle) in anti-NMDAR encephalitis. Arq. Neuro Psiquiatr. 2018, 76, 426. [CrossRef] [PubMed]

23. Kalita, J.; Misra, U.K. Markedly severe dystonia in Japanese encephalitis. Mov. Disord. 2000, 15, 1168-1172. [CrossRef]

24. Machado, A.; Chien, H.F.; Deguti, M.M.; Cançado, E.; Azevedo, R.S.; Scaff, M.; Barbosa, E.R. Neurological manifestations in Wilson's disease: Report of 119 cases. Mov. Disord. 2006, 21, 2192-2196. [CrossRef]

25. Chun, P.; Ying-Zi, H.; Yi, Y.; Hai-Bo, Q. Titration of high dose sedation is effective in severe tetanus: A case report. Cases J. 2009, 2, 6865. [CrossRef]

26. Verde, F.; Riboldi, G.; Zappa, C.; Ferretti, M.; Silani, V.; Mari, D.; Priori, A. An Old Woman with Pressure Ulcer, Rigidity, and Opisthotonus: Never For-get Tetanus! Lancet 2014, 384, 2266. [CrossRef]

27. Kira, S.; Sawada, N.; Aoki, T.; Kobayashi, H.; Takeda, M. Voiding Dysfunction Induced by Tetanus: A Case Report. Urol. Case Rep. 2016, 5, 6-8. [CrossRef]

28. Stoll, B.J. Tetanus. Pediatr. Clin. N. Am. 1979, 26, 415-431. [CrossRef]

29. Manjunatha, N.; Mehta, U.; John, P. Recurrent opisthotonus in catatonia: An atypical presentation. Indian J. Med. Sci. 2009, 63, 512-516. [CrossRef]

30. Bhatia, K.P.; Quinn, N.P.; Marsden, C.D. Clinical features and natural history of axial predominant adult onset primary dystonia. J. Neurol. Neurosurg. Psychiatry 1997, 63, 788-791. [CrossRef]

31. Sattar, M.; Hoque, H.W.; Amin, M.R.; Faiz, M.; Rahman, M.R.; Hoque, W. Neurological findings and outcome in adult cerebral malaria. Bangladesh Med. Res. Counc. Bull. 2009, 35, 15-17. [CrossRef] [PubMed]

32. Chauhan, V.V.; Pickens, A.T. Opisthotonus in Neurosyphilis: A Case Report. J. Emerg. Med. 2011, 41, 613-615. [CrossRef]

33. Laycock, G.J. Opisthotonos and Propofol: A Possible Association. Anaesthesia 1988, 43, 257. [CrossRef]

34. Jones, G.W.; Bykett, M.H.; Klok, M. Propofol Opisthotonus and Epilpesy. Anaesthesia 2007, 43, 905. [CrossRef]

35. Hofer, K.E.; Müller, D.M.; Wahl, S.; Rauber-Lüthy, C.; Ceschi, A.; Degrandi, C.; Zürrer-Härdi, U. Acute toxicity associated with the recreational use of the novel dissociative psychoactive substance methoxphenidine. Clin. Toxicol. 2014, 52, 1288-1291. [CrossRef] [PubMed]

36. Yates, C.; Lackey, A.; Campbell, R.; McEniery, J. Posterior fossa pilocytic astrocytoma presenting with opisthotonus in an infant-A case report. J. Clin. Neurosci. 2019, 68, 338-341. [CrossRef]

37. Balint, B.; Meinck, H.-M.; Bhatia, K.P. Axial Dystonia Mimicking Stiff Person Syndrome. Mov. Disord. Clin. Pract. 2015, 3, 176-179. [CrossRef]

38. Crabb, I.J.; Allan, L. Opisthotonus and Hysteria. Anaesthesia 1993, 48, 445-446. [CrossRef]

39. Bashir, H.H.; Jankovic, J. Treatment of Tardive Dyskinesia. Neurol. Clin. 2020, 38, 379-396. [CrossRef]

40. Kang, U.J.; Burke, R.E.; Fahn, S. Natural history and treatment of tardive dystonia. Mov. Disord. 1986, 1, 193-208. [CrossRef] [PubMed]

41. Krack, Y.; Schneider, S.; Deuschl, G. Geste Device in Tardive Dystonia with Retrocollis and Opisthotonic Pos-turing. Mov. Disord. 1998, 13, 155-156. [CrossRef]

42. Kiriakakis, V.; Bhatia, K.P.; Quinn, N.P.; Marsden, C.D. The natural history of tardive dystonia. A long-term follow-up study of 107 cases. Brain 1998, 121, 2053-2066. [CrossRef] [PubMed]

43. Niemann, N.; Jankovic, J. Treatment of Tardive Dyskinesia: A General Overview with Focus on the Vesicular Monoamine Transporter 2 Inhibitors. Drugs 2018, 78, 525-541. [CrossRef]

44. Knight, E.M.P.; Grinenko, O.; Bulacio, J.; Bingaman, W.; Gupta, A.; Chauvel, P. Arc de cercle as a manifestation of focal epileptic seizures. Neurol. Clin. Pract. 2018, 8, 354-356. [CrossRef] [PubMed]

45. Hou, J.-G.G.; Ondo, W.; Jankovic, J. Intrathecal baclofen for dystonia. Mov. Disord. 2001, 16, 1201-1202. [CrossRef] [PubMed]

46. Lizarraga, K.J.; Fasano, A. Effects of Deep Brain Stimulation on Postural Trunk Deformities: A Systematic Review. Mov. Disord. Clin. Pract. 2019, 6, 627-638. [CrossRef] [PubMed]

47. Narayan, R.; Loubser, P.; Jankovic, J.; Donovan, W.; Bontke, C. Intrathecal Baclofen for Intractable Axial Dysto-nia. Neurology 1991, 41, 1141-1142. [CrossRef] [PubMed]

48. Jankovic, J. Botulinum toxin: State of the art. Mov. Disord. 2017, 32, 1131-1138. [CrossRef]

49. Anandan, C.; Jankovic, J. Botulinum Toxin in Movement Disorders: An Update. Toxins 2021, 13, 42. [CrossRef]

50. Jankovic, J. An update on new and unique uses of botulinum toxin in movement disorders. Toxicon 2018, 147, 84-88. [CrossRef]

51. Davis, H. A Case of Opisthotonos Cured by Chloral-Hydrate. BMJ 1877, 1, 610. [CrossRef] 
52. Goldstein, E.M. Safety of high-dose botulinum toxin type A therapy for the treatment of pediatric spasticity. J. Child Neurol. 2006, 21, 189-192. [CrossRef] [PubMed]

53. Willis, A.W.; Crowner, B.; Brunstrom, J.E.; Kissel, A.; Racette, B.A. High dose botulinum toxin A for the treatment of lower extremity hypertonicity in children with cerebral palsy. Dev. Med. Child Neurol. 2007, 49, 818-822. [CrossRef]

54. Mesterman, R.; Gorter, J.W.; Harvey, A.; Lockhart, J.; McEwen-Hill, J.; Margallo, K.; Goldie, N. Botulinum Toxin Type a in Children and Adolescents with Severe Cerebral Palsy: A Retrospective Chart Review. J. Child Neurol. 2014, 29, 210-213. [CrossRef]

55. Guyot, P.; Kalyvas, C.; Mamane, C.; Danchenko, N. Botulinum Toxins Type A (Bont-A) in the Management of Lower Limb Spasticity in Children: A Systematic Literature Review and Bayesian Network Meta-analysis. J. Child Neurol. $2019,34,371-381$. [CrossRef] 